\title{
Reproductive behavior in the annual fish Austrolebias reicherti Loureiro \& García 2004 (Cyprinodontiformes: Rivulidae)
}

\author{
Daniel García ${ }^{1,2}$, Marcelo Loureiro ${ }^{1}$ and Bettina Tassino²
}

Annual fishes inhabit temporary ponds that dry out seasonally and the adaptations to survive this extreme condition include high metabolic rates and an elaborate courtship behavior which ends in the deposition of drought-resistant eggs, capable of going through diapause stages in the substrate. The pronounced sexual dimorphism that these fishes show suggests that sexual selection could play a key role in the differentiation, speciation and evolution of this diverse group of fishes. However, there is scarce information about their reproductive isolation mechanisms, including detailed analysis of courtship signals. Herein, we analyzed, qualitatively and quantitatively, the reproductive behavior of Austrolebias reicherti. The behavioral units recognized in this study correspond with the previous analysis of other species of annual fishes. The most frequent unit in males was the lateral display where specific morphological and coloration patterns are displayed to the female. The female's high relative frequency and time of quietness suggest that this unit may have an evaluation role during courtship. In addition to visual displays during courtship, males perform vibrations of the dorsal and anal fins as well as body undulations; these indicate that mechanical signals may be important for attracting females. Our results support the hypothesis of multimodal signals. The conservation of behavioral patterns in courtship displays within Austrolebias suggests that species-level recognition and the barrier to hybridization may not occur at this stage, unless quantitative differences can be identified.

Os peixes anuais habitam charcos temporários que secam sazonalmente, e as adaptações para sobreviver a estas condições extremas incluem altas taxas metabólicas e um elaborado comportamento de cortejo, que culmina com a deposição de ovos resistentes à dessecação dentro do substrato, os quais são capazes de atravessar estádios de diapausa. O pronunciado dimorfismo sexual apresentado por estes peixes indica que a seleção sexual poderia estar exercendo um papel chave na diferenciação, especiação e evolução deste grupo diverso de peixes. Entretanto, informações acerca dos mecanismos de isolamento reprodutivo, incluindo uma análise detalhada dos sinais de cortejo, são escassas. Neste artigo é analisado o comportamento reprodutivo de Austrolebias reicherti de maneira qualitativa e quantitativa. As unidades comportamentais utilizadas neste estudo correspondem àquelas incluídas em análises anteriores de outras espécies de peixes anuais. A unidade comportamental mais freqüentemente observada em machos foi a “exibição lateral”, onde características espécie-específicas da morfologia e colorido são exibidas para a fêmea. A alta proporção de ocorrência (em freqüência e tempo) do comportamento de "quietude" nas fêmeas indica que o mesmo poderia desempenhar um papel avaliativo durante o cortejo. Outros sinais além dos visuais estão envolvidos no cortejo dos peixes anuais; os machos vibram as nadadeiras dorsal e anal e ondulam o corpo, o que indica que os sinais mecânicos poderiam ter influência na atração das fêmeas. Estes resultados conferem suporte à hipótese de sinais multimodais, recentemente proposta. Os movimentos de cortejo altamente conservados dentro de Austrolebias indicam que o reconhecimento específico e a barreira à hibridização poderiam não ocorrer nesta etapa, a menos que se encontrem diferenças quantitativas nestes sinais comportamentais.

Key words: Courtship, Killifish, Patos-Merin system, Quantitative behavioral analysis.

\section{Introduction}

The family Rivulidae is one of the most specious taxa of the Neotropics, with several genera that show a unique annual life cycle (Costa, 1998; Vari \& Malabarba, 1998). Annual fishes inhabit temporary ponds that dry out seasonally and the adaptations to survive this extreme condition include high metabolic rates (Cardozo, 1999) and an elaborate courtship behav-

\footnotetext{
${ }^{1}$ Sección Vertebrados. Departamento de Biología Animal, Facultad de Ciencias, Universidad de la República. Iguá 4225. Montevideo 11400, Uruguay.

${ }^{2}$ Sección Etología. Departamento de Biología Animal, Facultad de Ciencias, Universidad de la República. Iguá 4225. Montevideo 11400, Uruguay.dgarcia@fcien.edu.uy
} 
ior (Vaz-Ferreira et al., 1964, 1972; Belote \& Costa, 2002, 2003, 2004) which culminates in the deposition of drought-resistant eggs in the substrate, where these eggs undergo diapause stages (Wourms, 1972). Another remarkable characteristic of many rivulids is their sexual dimorphism. In the genus Austrolebias Costa, 1998 (distributed along the Parana-La Plata basin and the Patos-Merin system) males of most species exhibit bright coloration on the opercular region and unpaired fins and a pattern of vertical bars or dots on body flanks; whereas females are brownish (with hues of yellow and/or green on the opercular region) with scattered dots (of diverse form) on body flanks and fins (Fig. 1). This pronounced dimorphism suggests that sexual selection could play a key role in the differentiation, speciation and evolution of this diverse group of fishes.

The Austrolebias adloffi species group (sensu Costa, 2006) is endemic to the Patos-Merín system. The group consists of at least five species, two of them having a parapatric distribution along the southwestern lowlands of laguna Merín (Loureiro \& García, 2006); A. reicherti Loureiro \& García 2004 to the north of arroyo Parao (rio Cebollatí basin) and $A$. charrua Costa \& Cheffe 2001 to the south of this river. Furthermore, the area of contact is diffuse, and it has been proposed as a hybrid zone (García et al., 2004; Loureiro \& García, 2006).

Despite that these interesting evolutionary processes (i.e., sexual selection and hybridization) may be acting in these species, there is scarce information about their reproductive isolation mechanisms, including detailed analysis of courtship signals. Belote \& Costa (2004) qualitatively described the reproductive behavior of $A$. charrua; the general pattern of displays they observed corresponded to those previously reported for other species in the genus (Vaz-Ferreira \& Sierra, 1964, 1972). However, no information is available for the parapatric A. reicherti. The goal of this study was to analyze, qualitatively and quantitatively, the reproductive behavior of this species.

\section{Materials and Methods}

Fishes were obtained through field sampling in the type locality of the species (32 $55^{\prime}$ 'S, 53 $54^{\circ}$ 'W) using hand nets; specimens were transported to the laboratory where sexes were kept separately. Aquariums were kept at room temperature and constantly aerated; the fish were fed daily with live Tubifex sp.
Courtship behavior was observed in a special aquarium (33 x $15 \times 25 \mathrm{~cm}$ ) with the bottom completely covered with peat moss, $10 \mathrm{~cm}$ deep, resembling the natural substrate inhabited by annual fishes. Each trial consisted of one male and one female interacting for a period of $30 \mathrm{~min}$, recorded with a Panasonic PV-DV 100 video camera. Each individual was tested only once and the total number of trials was 10 .

Video recordings were analyzed with a Panasonic NV-HS 1000 video player. First, we defined the behavioral units of the courtship pattern. Subsequently, a complete sequence of these units was made simultaneously for males and females. This sequence was used to analyze the transition of behavioral units, and the frequency and duration of each unit in both sexes. From this data, flow diagrams for both sexes were constructed. Finally, the sequence was divided into three 10min periods to analyze the time variation in the appearance of behavioral units in males. After the experiments, the fish were sacrificed with 2-phenoxyethanol and fixed in formalin (10\%). Voucher specimens were deposited in the Vertebrates Collection of Facultad de Ciencias, Universidad de la República, Uruguay (Institutional code ZVC-P, Lot number 6965).

\section{Results}

Eight behavioral units in males and five in females were identified. Units appearing only occasionally (one time) were removed from the analysis. The description of the most representative courtship displays of males and females with their relative frequency and duration time are shown in Table 1.

Sequence of behavioral units. Males exhibited a pale coloration when first introduced in the aquarium, with coloration intensifying when approaching a female. The reproductive behavior begins with the male alternating lateral displays (LD) with sigmoid displays (SD); when the female responds by swimming towards the male, two pathways may occur: the male may display an invitation to dive (ID) or an invitation to follow (IF). In the first case, if the female displays a diving acceptance (DA) the pair dives toward the substrate and mating (M) occurs. In the second case, the male may move to a different place in the aquarium and display another ID. If the female does not follow the male, then the male initiates a whole new sequence of displays (Fig. 2).

The flow diagram obtained for males Austrolebias reicherti

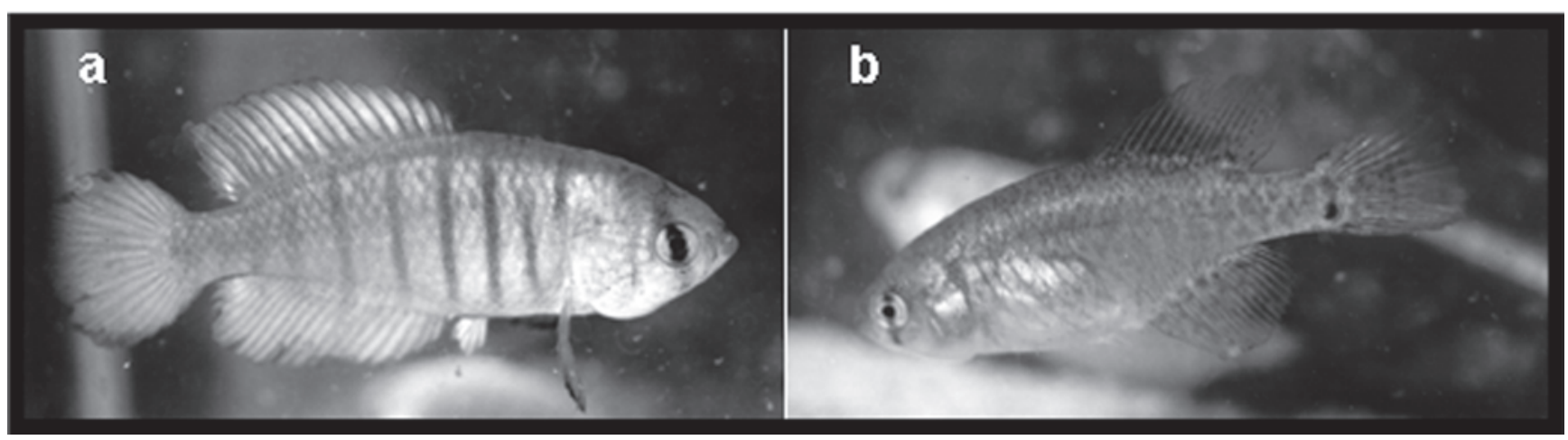

Fig. 1. Male (a) and female (b) of Austrolebias reicherti. 


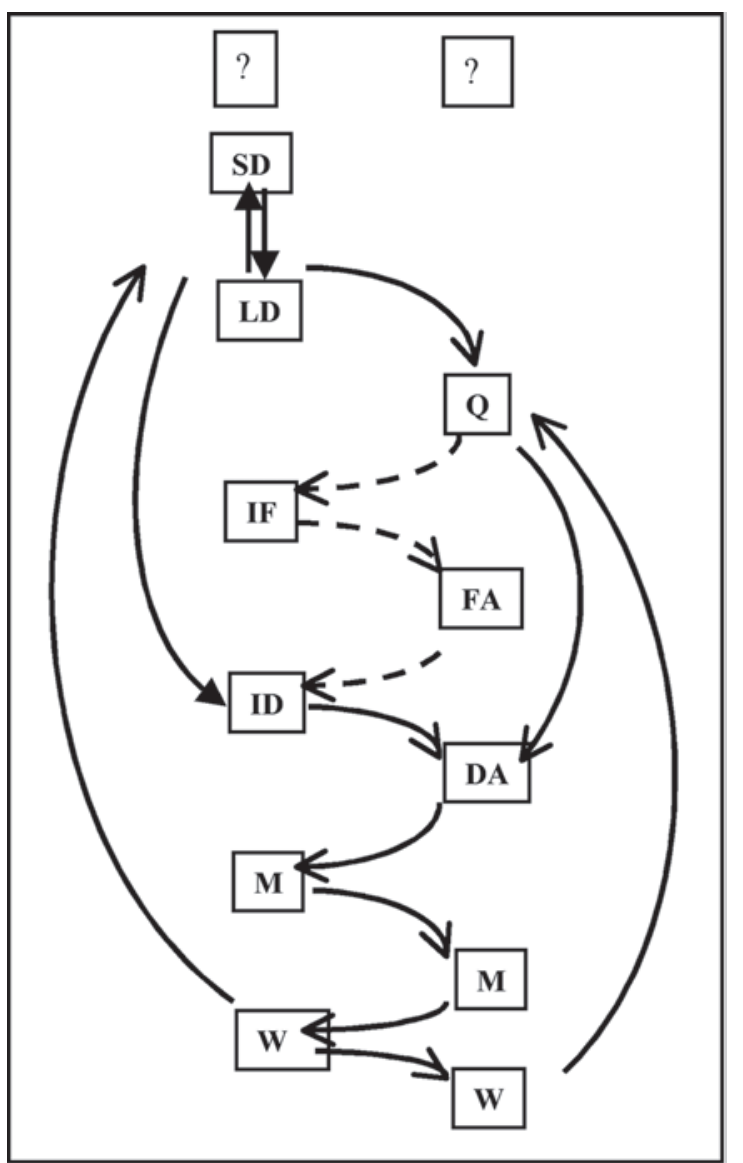

Fig. 2. Schematic diagram of behavioral units of sequence of courtship and mating in Austrolebias reicherti. Abbreviations of units shown in Table 1. Broken lines indicate alternative (less frequent) sequence.

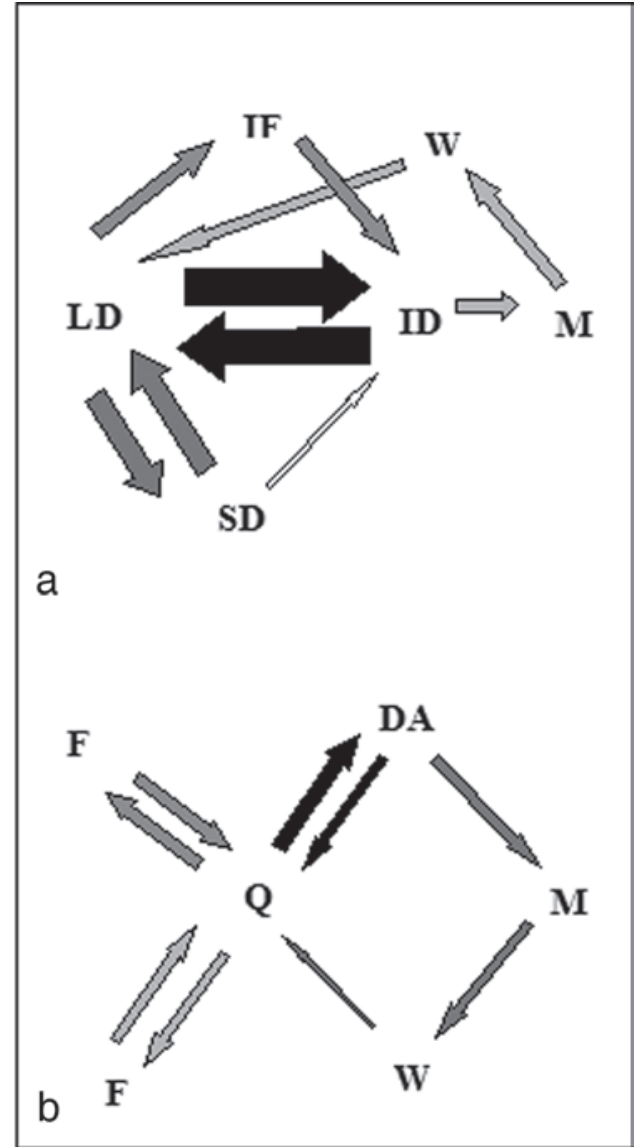

Fig. 3. Flow diagram of behavioral units of transitions of males (a) and females (b) in Austrolebias reicherti. Thickness of arrows is proportional to frequency of transitions. Abbreviations of units shown in Table 1.

Table 1. Behavioral unit description, relative frequency and time of males and females of Austrolebias reicherti; $\mathrm{SD}=$ standard deviation.

\begin{tabular}{|c|c|c|c|c|c|c|}
\hline \multicolumn{2}{|c|}{ Behavioral Units } & \multirow[t]{2}{*}{ Description } & \multicolumn{2}{|c|}{$\begin{array}{l}\text { Relative frequency } \\
(\text { mean } \pm \text { SD) }\end{array}$} & \multicolumn{2}{|c|}{$\begin{array}{l}\text { Relative time } \\
\text { (mean } \pm \text { SD) }\end{array}$} \\
\hline & & & males & females & males & females \\
\hline \multicolumn{2}{|c|}{ Males } & & & & & \\
\hline $\begin{array}{l}\text { Lateral } \\
\text { display }\end{array}$ & LD & $\begin{array}{l}\text { Body still, dorsal and anal fins extended, which may vibrate or } \\
\text { not }\end{array}$ & $0.32 \pm 0.12$ & & $0.38 \pm 0.19$ & \\
\hline $\begin{array}{l}\text { Sigmoid } \\
\text { display }\end{array}$ & SD & Lateral display with body undulations & $0.12 \pm 0.06$ & & $0.05 \pm 0.03$ & \\
\hline $\begin{array}{l}\text { Invitation } \\
\text { to follow }\end{array}$ & IF & Successive short swimming away and stops & $0.06 \pm 0.04$ & & $0.04 \pm 0.03$ & \\
\hline $\begin{array}{l}\text { Invitation } \\
\text { to dive }\end{array}$ & ID & $\begin{array}{l}\text { Body in vertical or oblique position, with head over the } \\
\text { substrate, and vibration of extended dorsal and anal fins }\end{array}$ & $0.27 \pm 0.09$ & & $0.15 \pm 0.06$ & \\
\hline Mating & M & $\begin{array}{l}\text { Body placed by the side of female, pressing its body to the } \\
\text { substrate. Unit performed from near the surface to completely } \\
\text { buried }\end{array}$ & $0.05 \pm 0.04$ & & $0.05 \pm 0.04$ & \\
\hline \multicolumn{2}{|c|}{ Females } & & & & & \\
\hline $\begin{array}{l}\text { Following } \\
\text { Acceptance }\end{array}$ & FA & Female follows male (displaying IF) & & $0.11 \pm 0.06$ & & $0.03 \pm 0.03$ \\
\hline $\begin{array}{l}\text { Diving } \\
\text { acceptance }\end{array}$ & DA & Females placed by the side of male touching its body & & $0.21 \pm 0.05$ & & $0.03 \pm 0.01$ \\
\hline Mating & M & $\begin{array}{l}\text { Female buried in the substrate (partially or completely) } \\
\text { together with male }\end{array}$ & & $0.1 \pm 0.05$ & & $0.07 \pm 0.05$ \\
\hline \multicolumn{2}{|c|}{ Shared units } & & & & & \\
\hline Quietness & Q & Body still & $0.06 \pm 0.10$ & $0.37 \pm 0.07$ & $0.24 \pm 0.24$ & $0.71 \pm 0.15$ \\
\hline Wait & W & Individual remains still over the substrate after mating & $0.05 \pm 0.04$ & $0.1 \pm 0.05$ & $0.08 \pm 0.05$ & $0.08 \pm 0.05$ \\
\hline Escape & $\mathrm{E}$ & Individual swims away from each other & $0.17 \pm 0.23$ & $0.16 \pm 0.13$ & $0.001 \pm 0.001$ & $0.08 \pm 0.06$ \\
\hline
\end{tabular}


(Fig. 3a) shows that the most frequent transition events was between ID and LD, followed by a shift from LD to SD; the transition between LD and IF was also observed. On the other hand, the most frequent behavioral circuits in females were those related to quietness $(\mathrm{Q})$ and mating $(\mathrm{M})$ (Fig. 3b).

Quantitative Analysis. The most frequent display of males was LD, followed by ID, SD and IF; whereas in females the most frequent display was $\mathrm{Q}$, followed by diving acceptance (DA), following acceptance (FA), M, and wait (W) (Table 1; Fig. 4a). Concerning the relative time of displays in males, LD was the most common display, followed by Q, and ID; in females $\mathrm{Q}$ was the most common display, followed by $\mathrm{W}$ and M (Table 1; Fig. 4b).

The following observations were made in relation to variation of frequency of units over time of experiment in males (Fig. 5a): Q was most frequent (circa 0.15) in the first and last intervals; LD showed a high frequency in all intervals, reaching the highest frequency in the second (0.35); SD was most frequent in the first and second interval with a frequency higher than 0.15 , and the same occurred with IF; ID increased in relative frequency along the experiment, less than 0.25 in the first interval, to more than 0.25 in the second, and higher than 0.3 in the last one; $\mathrm{M}$ and $\mathrm{W}$ were higher in the first interval (0.1). In the analysis of relative time (Fig. 5b), the same pattern was observed, with the exception of $M$ which increased in duration with time. Most displays were observed in the second interval.

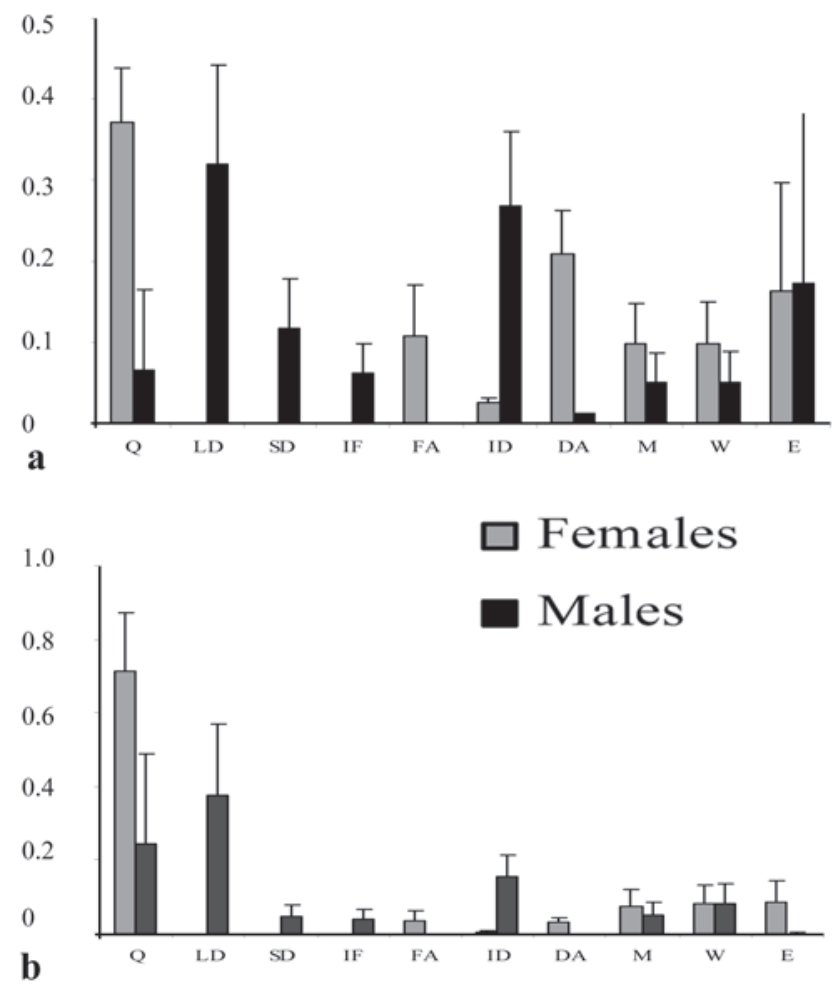

Fig. 4. Relative frequency (a) and time (b) of behavioral units of males and females in Austrolebias reicherti. Abbreviations of units shown in Table 1.

\section{Discussion}

The behavioral units (displays) defined in this study corresponded to the categories recognized in previous analyses of other species of annual fishes. Vaz-Ferreira et al. (1964) briefly described the reproductive behavior, without division of units, in Austrolebias bellottii, A. nigripinnis, A. viarius, A. luteoflammulatus, and A. cheradophilus. Several categories identified by those authors correspond to the units defined herein: dorsal and anal fin vibration in an extended position, fast and alternate movements, and repetitive action of substrate penetration. Vaz-Ferreira \& Sierra (1972) defined display units in a social and reproductive context in A. viarius, A. luteoflammulatus, A. bellottii, and A. nigripinnis; many of which are equivalent to those defined in this study (lateral display, sigmoid display, invitation to follow, invitation to dive, mating, and wait). Recently, Belote \& Costa (2004) analyzed the reproductive behavior of three species of Austrolebias (A. cyaneus, A. nigripinnis and A. charrua). These authors divided courtship behavior into five steps, each of them corresponding to one or more of the units described herein: Step 1 (courtship displays) includes lateral display, sigmoid display, invitation to follow; Step 2 (invitation to submerge) corresponds to invitation to dive; Step 3 (submerging) corresponds to diving acceptance; Step 4 (spawning/fertilization) corresponds to mating; and Step 5 (emerging) corresponds to wait. However, fine-scaled behavioral observations are always preferred in order to understand and discern specific
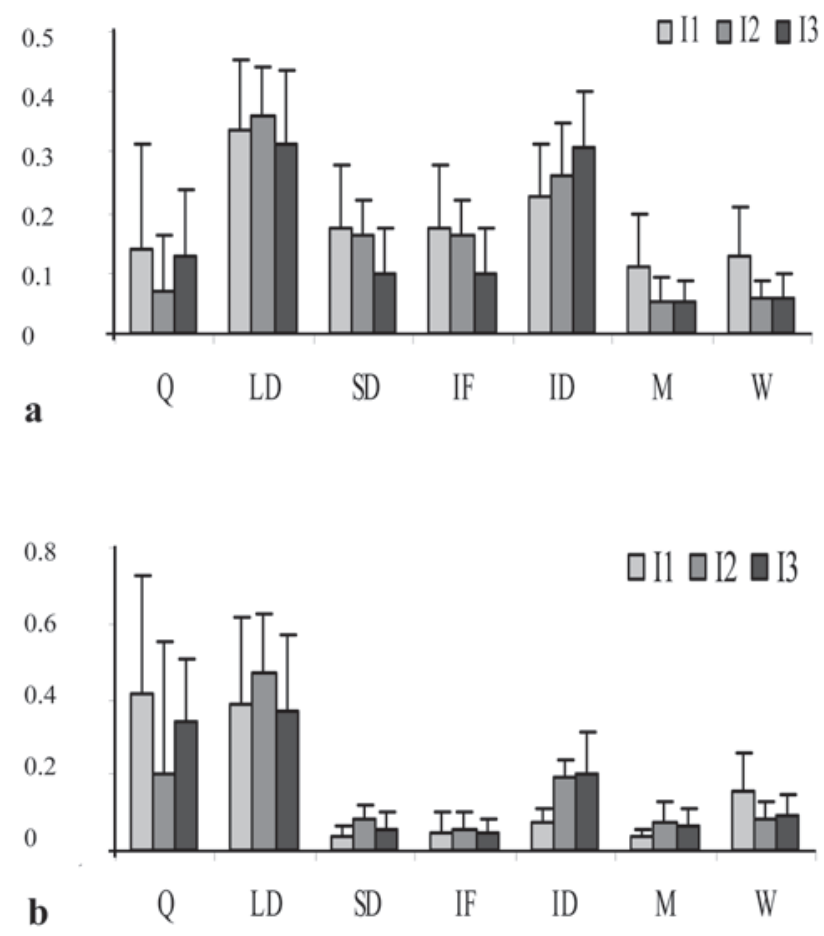

Fig. 5. Relative frequency (a) and time (b) of behavioral units of males in Austrolebias reicherti at 10-min time intervals. I1: first interval; I2: second interval; I3: third interval. 
differences since it allows more precise quantification in comparative analyses. In this case, we showed that the units that compose the "courtship displays" of Belote \& Costa (2004) have different frequencies and may appear in a different sequence, which justifies the adoption of a more detailed division of the behavioral units in the present study.

Reproductive behavior in species of Austrolebias is similar to that observed for species of related genera, e.g., Simpsonichthys (Belote \& Costa, 2002). Differences in some stages of the reproductive behavior can be alternatively interpreted as specifically derived conditions or morphologic constraints. For example, many species with elongated unpaired fin rays, fold these fins in courtship behavior, which would be difficult to achieve in species with long fin bases and all fin rays of the same length (such as Austrolebias). Fin folding was observed in other Cynolebiatinae genera such as Cynopoecilus, Leptolebias, and Campellolebias (Vaz-Ferreira \& Sierra, 1974; Costa et al., 1988), in some species of Simpsonichthys (Belote \& Costa, 2002), as well as in the distantly related annual fish species of the African Aplocheilidae, Notobranchius guentheri (Haas, 1976).

The high relative frequency and long duration of quietness and its high importance in the flow analysis in females indicates that it may have an evaluator role during courtship. Females of annual fishes carry few oocytes at a given time. Simpson (1979) indicated that females of A. bellottii lay between 8 and 12 oocytes each day, which may be interpreted as a limiting factor in the reproduction of these species. In this sense, female quietness may represent a way to assure species recognition and/or male fitness, thereby enhancing the chances of reproductive success. Both lines of evidence, together with sexual dimorphism, suggest that sexual selection is likely a strong evolutionary factor in the speciation processes of annual fishes, with female choice playing a key role in their evolution.

The high frequency and long duration of quietness in males, in the first 10 min of the experiment, may reflect an acclimation time for individuals to the test aquarium. In the following period is when a higher number of mating units occurred, decreasing in frequency during the third time interval. Lateral display was observed in higher frequency in the second interval while sigmoid display had the same frequency in the first and second intervals. However, both units lasted longer in the second interval; indicating that in the beginning the male may be investing energy in attracting the female. It is also interesting to note the apparent relation of invitation to dive and mating; while frequency and time of the first unit increases over time, the frequency of the second decreases and its duration increases. This could indicate a loss of female energy and motivation along the reproduction event. The male continues to try mating, while the female becomes less receptive, resulting in a decrease in mating.

Other signals besides vision seem to be involved in the courtship of annual fishes. As was observed in lateral display and invitation to dive, where males perform vibrations of dorsal and anal fins, and in sigmoid display where the body undulates, mechanical signals seem to be very important in attracting females. Differences in fin morphology (i.e., dorsal fin base length) between species (Costa \& Cheffe, 2001) and within species (D'Anatro \& Loureiro, 2005) are common in Austrolebias. Do these differences in fin morphologies result in different signals when vibrating? No study has assessed this variation yet. Sound production by head movements has also recently been observed in one species of Cynolebias (Belote \& Costa, 2003). Annual fishes have a highly developed cephalic lateral line system, suggesting the importance of extra-visual displays in this group of fishes. Furthermore, it would be interesting to explore the chemical signals that these fishes may be using. Previous reports showed that females Xiphophorus pygmaeus (Poeciliidae) prefer chemical signals from males of their own species than those from a sympatric species ( $X$. cortezi; Hankison \& Morris, 2003). These results support the hypothesis of backup signals proposed by Johnstone (1996), which indicates that multimodal signals allow a more precise evaluation of the sender condition (Candolin, 2003; Hebets \& Papaj, 2005).

The high conservancy in courtship displays within Austrolebias, indicates that specific recognition and the barrier to hybridization may not occur at this stage, unless there are quantitative differences in courtship displays or in the aforementioned non-visual signals. High individual variability in frequency and duration of displays has been recorded by quantitative analysis. This kind of approach allows an objective and detailed comparison among species to elucidate the incidence of reproductive behavior in population differentiation, eventual speciation, and the establishment of reproductive barriers between lineages (Peretti \& Córdoba-Aguilar, 2007). As mentioned before, A. reicherti is distributed parapatrically with $A$. charrua (Loureiro, 2004; Loureiro \& García, 2006), with a zone of contact in arroyo Parao (río Cebollati basin). Unfortunately, quantitative analyses of A. charrua and other species of annual fish genera for comparative purposes are lacking.

\section{Acknowledgments}

This study was partially funded by CSIC (Comisión Sectorial de Investigación Científica, Universidad de la República, Uruguay) through a grant to Marcelo Loureiro. Special thanks go to Jansen Zuanon for the translation of the abstract to Portuguese and also A. Leyva for English editing of the manuscript.

\section{Literature Cited}

Belote, D. F. \& W. J. E. M. Costa. 2002. Reproductive behavior patterns in the neotropical annual fish genus Sympsonichthys Carvalho, 1959 (Cyprinodontiformes, Rivulidae): description and phylogenetic implications. Boletim do Museu Nacional, Nova Série, Rio de Janeiro, 489:1-10. 
Belote, D. F. \& W. J. E. M. Costa. 2003. Reproductive behavior of the Brazilian annual fish Cynolebias albipunctatus Costa \& Brasil, 1991 (Teleostei, Cyprinodontiformes, Rivulidae): a new report of sound production in fishes. Arquivos do Museu Nacional, Rio de Janeiro, 61 (4): 241-244.

Belote, D. F. \& W. J. E. M. Costa. 2004. Reproductive behavior patterns in three species of the South American annual fish genus Austrolebias Costa, 1998 (Cyprinodontiformes, Rivulidae). Boletim do Museu Nacional, Nova Série, Rio de Janeiro, 514: 1-7.

Candolin, U. 2003. The use of multiple cues in mate choice. Biological Review, 78: 575-595.

Cardozo, V. 1999. Tasa Metabólica y excreción del nitrógeno en peces anuales Cynolebias viarius (Cyprinodontiformes). Unpublished M.Sc. Thesis, PEDECIBA, Universidad de la República, Montevideo.

Costa, W. J. E. M. 1998. Phylogeny and classification of Rivulidae revisited: origin and evolution of annualism and miniaturization in rivulid fishes (Cyprinodontiformes: Aplocheiloidei). Journal of Comparative Biology, 3:33-92.

Costa, W. J. E. M. 2006. The South American annual killifish genus Austrolebias (Teleostei: Cyprinodontiformes: Rivulidae): phylogenetic relationships, descriptive morphology and taxonomic revision. Zootaxa, 1213: 1-162.

Costa, W. J. E. M. \& M. M. Cheffe. 2001. Three new annual fishes of the genus Austrolebias from the Laguna dos Patos system, Southern Brazil, and a re-description of A. adloffi (Ahl) (Cyprinodontiformes: Rivulidae). Comunicações do Museu de Ciência e Tecnologia, PUCRS, Série Zoologia, Porto Alegre, 14(2):179-200.

Costa, W. J. E. M., M. T. C. Lacerda \& K. Tanikazi. 1988. Description d'une nouvelle espece de Cynolebias dès cotieres du Brasil sud-oriental (Cyprinodontiformes, Rivulidae). Revue Francaise d'Aquariologie et Herpetologie, 15:21-24.

D’Anatro, A. \& Loureiro M. 2005. Geographic variation in the annual killifish Austrolebias luteoflamulatus Vaz Ferreira, Sierra \& Scaglia (Cyprinodontiformes, Rivulidae). Journal of Fish Biology, 67:849-865.

García, G., S. Claramunt \& A. I. Lalanne. 2004. Genetic differentiation among annual fishes of the genus Cynolebias (Cyprinodontiformes, Rivulidae) in a Biosphere Reserve site from Uruguay. Environmental Biology of Fishes, 70: 247-256.

Haas, R. 1976. Behavioral Biology of the annual killifish, Notobranchius guentheri. Copeia, 1976(1): 80-91.
Hankison, S. J. \& M. R. Morris. 2003. Avoiding a compromise between sexual selection and species recognition: female swordtail fish assess multiple species-specific cues. Behavioral Ecology, 14 (2): 282-287.

Hebets E. A. \& D. R. Papaj. 2005. Complex Signal Function: developing a framework of testable hypotheses. Behavioral Ecology and Sociobiology, 57: 197-214.

Johnstone, R. A. 1996. Multiple displays in animal communication: "backup signals" and "multiple messages". Philosophical Transactions of the Royal Society of London B, 351:329-338.

Loureiro, M. 2004. Sistemática y biogeografía de los peces anuales de la subtribu Cynolebiatina (Cyprinodontiformes: Rivulidae: Cynolebiatinae). Unpublished Ph.D. Thesis, PEDECIBA, Universidad de la República, Montevideo, 119p.

Loureiro, M. \& G. García. 2006. Transgresiones y regresiones marinas en la costa atlántica y lagunas costeras del Uruguay: efectos sobre los peces continentales, Pp. 545-555. In: Menafra, Rodríguez, Scarabino \& Conde (Eds.). Bases para la conservación y el manejo de la costa uruguaya. Montevideo, Vida Silvestre, $667 \mathrm{pp}$.

Peretti, A. V. \& A. Córdoba-Aguilar. 2007. On the value of finescaled behavioural observations for studies of sexual coercion. Ethology, Ecology and Evolution, 19:77-86.

Simpson, B. R. C. 1979. The phenology of annual killifishes. Symposium of the Zoological Society of London, 44:243-261.

Vari, R. P., L. R. Malabarba. 1998. Neotropical Ichthyology: an overview. Pp. 1-11. In: Malabarba L. R., R. E. Reis, R. P. Vari, Z. M. Lucena \& C. A. S. Lucena (Eds.). Phylogeny and Classification of Neotropical Fishes. Porto Alegre, Edipucrs, 603p.

Vaz-Ferreira, R. \& B. Sierra. 1972. Caracteres etológicos genéricos y específicos en los peces del género Cynolebias Steindachner. Boletín de la Sociedad Zoológica del Uruguay, 2: 22-35.

Vaz-Ferreira, R., B. Sierra \& S. Scaglia. 1964. Eco-etología de la reproducción en los peces del género Cynolebias Steindachner, 1876. Apartados de los Archivos de la Sociedad de Biología de Montevideo, 26:44-49.

Wourms, J. P. 1972. The developmental biology of the annual fishes. Pre-embryonic and embryonic diapause of variable duration in the eggs of annual fishes. Journal of Experimental Zoology, 182: 389-414.

Accepted February 2008 Published June 28, 2008 